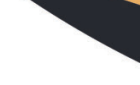

This is an open article under the CC-BY-SA license

\title{
INOVASI DECOUPAGE UNTUK INOVASI PEMBERDAYAAN PEREMPUAN DESA TEGAREN, TRENGGALEK
}

\author{
Herlina Suksmawati ${ }^{1}$, Arin Setiyowati ${ }^{2}$, Ayu Rikza ${ }^{3}$, Praja Firdaus Nuryananda ${ }^{4}$ \\ ${ }^{1,3,4}$ UPN "Veteran" Jawa Timur \\ ${ }^{2}$ Universitas Muhammadiyah Surabaya \\ herlinasuksma@gmail.com¹, arin.st@fai.um-surabaya.ac.id², ayurikza.hi@gmail.com³ , firdaus.praja@gmail. \\ $\mathrm{com}^{4}$
}

Submitted: 23 September 2021 Accepted: 12 Desember 2021 Published : 31 Desember 2021

\begin{abstract}
Abstrak
Kegiatan pengabdian ini berfokus pada pemberdayaan perempuan lokal Desa Tegaren, Kabupaten Trenggalek, dengan instrumen produk kerajinan besek bambu berteknik decoupage (pewarnaan) untuk meningkatkan kapasitas ekonomi desa sekaligus menaikkan kesejahteraan keluarga. Beberapa kelompok perempuan lokal telah menjadikan produk kerajinan bambu sebagai salah satu karya yang menghasilkan penghasilan tambahan untuk keluarga mereka. Namun demikian, para perempuan lokal tersebut terbukti masih belum mampu mengembangkan produk kerajinan bambu yang mereka tekuni. Oleh karena itu, dengan menggunakan pendekatan pemberdayaan masyarakat observasi partisipatif, pengabdian masyarakat ini akan bertumpu pada peran perempuan lokal Tegaren untuk meningkatkan kapasitas ekonomi sosial mereka dan desa. Beberapa konsep teoretik yang digunakan dalam pengabdian masyarakat ini adalah penyuluhan sosial, pendampingan, pelatihan, decoupage, peningkatan kapasitas ekonomi (economic leverage), metode asset-based community development (ABCD), dan pemberdayaan perempuan. Hasil utama dari kegiatan pengabdian masyarakat ini termanifestasikan menjadi dua, yakni (1) peningkatan kapasitas perempuan pengrajin besek bambu sehingga mereka dapat membuat besek dengan teknik decoupage dan (2) besek hasil karya mereka dapat dijadikan sebagai bingkisan wisata desa.
\end{abstract}

Kata Kunci: Pemberdayaan Perempuan, Besek, Peningkatan Kapasitas Ekonomi, Desa 


\section{PENDAHULUAN}

Desa Tegaren adalah salah satu desa dari 152 desa keseluruhan di Kabupaten Trenggalek. Desa Tegaren sendiri termasuk dalam wilayah administrasi Kecamatan Tugu. Dengan dua dusun yang membagi wilayahnya, yakni Krajan dan Tompe, Desa Tegaren memiliki luas wilayah 522,76 Ha yang 120 Ha luasnya merupakan kawasan hutan negara yangdikelola oleh Perum Perhutani.

Sebagaimana desa yang terletak pada wilayah hutan dan pegunungan pada umumnya, Desa Tegaren merupakan desa agraris. Mayoritas warga Desa Tegaren bermatapencaharian sebagai petani yang terbagi menjadi dua jenis, yakni: a) petani yang memiliki lahan sendiri baik mengelola lahan tersebut secara mandiri ataupun mempekerjakan buruh dan b) petani subsisten yang bekerja sebagai buruh untuk menghidup sehari-hari. Selain pertanian, beberapa jenis produksi juga tumbuh di Tegaren, diantaranya, peternakan ayam, kambing, dan sapi serta produksi batu bata yang terbatas dilakukan ketika musim kemarau.

Proses-proses produksi di Desa Tegaren tersebut mayoritas dilakukan oleh para laki-laki.

Sedangkan perempuan, dalam sistem sosial-ekonomi masyarakat Tegaren, banyak bekerja di dalam rumah untuk mengurusi segala pekerjaan domestik dan penjagaan di samping juga terlibat aktif dalam aktivitas pertanian. Namun, seiring berjalannya waktu, para perempuan di Desa Tegaren telah memulai usaha produksi rumahan dengan menjadi pengrajin besek sejak era 900-an.

Kerajinan bambu berupa besek di Tegaren masih banyak kita jumpai saat ini, terutama didusun Tompe. Secara statistik, berdasarkan data observasi penulis, lebih dari75\% populasi perempuan yang ada di Desa Tegaren merupakan para pengrajin besek. Para pengrajinnya memiliki identitas yang beragam secara umur, tetapi mayoritas dilakukan oleh perempuanperempuan yang telah menikah.

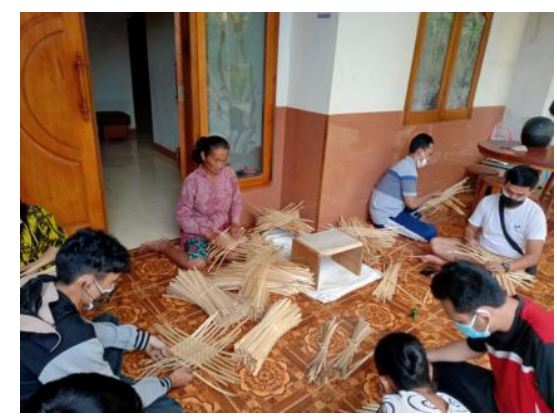

Gambar 1. Pembelajaran membuat besek di Tegaren 
(sumber: dokumentasi tim pengabdian masyarakat, 2021)

Besek dipilih sebagai salah satu komoditas dikarenakan berbagai hal. Pertama, modal produksi besek cukup murah karena raw materials berupa bambu mudah didapat dan murah. Kedua, proses produksi yang tidak memakan waktu dan tempat (fleksibel) sehingga bisa dilakukan kapan dan dimana saja ketika waktu senggang dan bisa dikerjakan bersamaan dengan proses interaksi masyarakat desa yang masih erat. Ketiga, tingkat produksi yang tidak rumit dan lebih cepat dibanding jenis kerajinan yang sejenis. Motivasi menjadi pengrajin besek yang merupakan komoditas produksi turuntemurun ini bermacam-macam. Akan tetapi faktor utama yang mendorong para perempuan menciptakan industri mereka sendiri adalah sebab persoalan perekonomian keluarga yang ditopang laki-laki belum mencapai ukuran sejahtera.

Namun, akibat dari kondisi geografis dan politis desa yang terletak di daerah pinggiran, hal ini menyebabkan masyarakat/warga Desa Tegaren seakan terjauhkan dari hingar bingarkota dan kemampuan untuk akses pengetahuan dan pengalaman lebih banyak. Hal tersebut berdampak pada kapasitas dan kapabilitas sumber daya manusiayang ada dan keputusasaan para pemuda akan peluang ekonomi di dalam desa tersebut, tidak terkecuali produksi besek di Desa Tegaren.

Permasalahan dalam produksi besek di Tegaren cukup beragam dan saling terkait satu sama lain sehingga menyebabkan adanya stagnasi industri rumahan. Pertama, dalam proses produksi, akibat kapabilitas individu yang tidak memadai, prosesproduksi tidak menjumpai berbagai inovasi. Produk diproduksi hanya dengan berbagai variasi ukuran, bukan jenisnya sehingga terkesan monoton. Kedua, kapabilitas para perempuan yang tidak mau menerima risiko kesulitan dalam mengimprovisasi produksi sehingga nyaman dengan proses produksi dengan satu jenis produk besek. Ketiga, pengorganisasian kolektif yang tidak berkembang sehingga tidak dapat menjangkau pasar dengan lebih kreatif dan luas. Besek dikumpulkan oleh masing-masing individu ke tengkulak sehingga harga jualnya cukup murah sehingga berakibat pada kontributifnya hasil produksi besek untuk meningkatkan taraf ekonomi keluarga.

Terakhir, ketiadaan lembaga yang kuat untuk membantu manajemen 
produksi, distribusi, dan perputaran uang pengrajin menjadikan produksi besek tidak maju. Padahal lembaga ini setidaknya dapat menghubungkan pengrajin dengan pasar secara langsung guna memangkas ongkos produksi sehingga dapat menjamin keberlanjutan insdustri dengan adanya berbagai topangan lembaga dengan sistem dan manajemen yang baik seperti koperasi yang berguna untuk memutar dan mengembangkan uang hasil produksi pengrajin. Akibat dari permasalahan tersebut, para pengrajin tidak bisa mengangkat taraf ekonomi dan sosial para pengerajin besek dan para perempuan muda yang tidak menjumpai peluang masa depan memilih untuk meninggalkan produksi ini.

Persoalan-persoalan yang telah dipaparkan sebelumnya membutuhkan solusi yangkomprehensif dan tidak parsial.Pemberdayaan perempuan dalam konteks pembangunan ekonomi lokal diperlukan dilakukan secara partisipatif agar sesuai dengan kebutuhan masyarakat. Kontekstualisasi problem produksi besek oleh para perempuan di Desa Tegaren, pemberdayaan ini bertujuan agar para pengrajin besek bambu dapat meningkatkan economic leverage (peningkatan harga jual) komoditas besek bambu dan perluasan pasar. Sehingga dengan adanya peningkatan harga jual maka diharapkan adanya pertumbuhan taraf kehidupan sosial ekonomi penduduk di Desa Tegaren, khususnya para perempuan pengrajin besek bambu.

\section{TINJAUAN PUSTAKA}

Pemberdayaan mulanya merupakan pendekatan pembangunan alternatif dari gerakan akar rumput di wilayah Global South yang berposisi sebagai protes terhadap pembangunan di Selatan yang top down, berorientasi pada modernisas $\mathrm{i}$, dan kurang kontributif terhadap perubahan hidup para perempuan (Buckley, 2000). Pemberdayaan muncul merespon pendekatan Gender and Development (GAD) yang muncul pada era 1980-an di mana pendekatan ini menekankan pada pentingnya konstruksi sosial dari gender dan tugas peran spesifik, tanggung jawab, dan ekspektasi terhadap laki-laki dan perempuan (Buckley, 2000). Pemberdayaan muncul sebagai pendekatan yang menekankan pada distribusi kekuasaan di semua level dan daya lanting yang mewajibkan akses terhadap sumber daya intangible, yakni kemampuan analisis, jaringan sosial, kekuatan organisasional, solidaritas, dan 
perasaan tidak berdiri seorang diri (Buckley, 2000). Pemberdayaan bergerak jauh dari kebergantungan terhadap rencana pembangunan untuk membawa perubahan atau ide perubahan lewat agensi dan partisipasi (Buckley, 2000). Implementasi berfokus pada kelompok serta dipromosikan melalui strategi-strategi organisasi kelompok, peingkatan kesadaran, dan pendidikan popular. Lambat laun istilah dan konsep pemberdayaan dipakai sedemikian rupa oleh berbagai akademisi, praktisi, dan organisasi baik dari level lokal hingga internasional, pemerintah maupun nonpemerintah. Saat ini, pemberdayaan perempuan menjadi salah satu pilar kesetaraan gender yang mana merupakan pasal kelima dalam 17 poin Sustainable Development Goals (SDGs).

Namun, pada perkembangannya pengertian dan bagaimana melakukan serta mengukur pemberdayaan dikontestasikan sedemikian rupa oleh para akademisi dan praktisi pembangunan. Tidak semua orang sepakat atas satu definisi dan cara pengukuran tertentu sehingga setiap orang dengan berbagai latar belakang dapat melakukan pemberdayaan dengan definisi, aplikasi, dan pengukuran versi mereka sendiri yang dinilai telah merepresentasikan

kebutuhan

masyarakat sasaran. Hal tersebut sebagaimana telah diungkapkan oleh Batliwala (Kabeer, McFadden, Arnfred, Dominguez, \& Saadallah, 2001) bahwa ketidakjelasan definisi pemberdayaan memberikan kita ruang bernapas untuk melakukan pemberdayaan dalam kerjakerja dan akan terus melakukan kerjakerja tersebut hingga mereka tidak lagi dideskripsikan sebagai pemberdayaan.

Namun, agar terhindar dari kerangka berpikir yang tidak kuat dalam implementasi, penulis telah mengambil satu definisi pemberdayaan-dalam hal ini adalah pemberdayaan ekonomi perempuan —sebagai pijakan bagaimana proses pemberdayaan akan dilakukan terhadap komunitas perempuan pengrajin besek di Desa Tegaren. Definisi tersebut adalah bahwa pemberdayaan merupakan sebuah proses yang berorientasi pada perbuahan multidimensional yang meliputi berbagai aspek hidup para perempuan dengan hasil yang berbeda-beda pada berbagai tingkat, yakni individu, keluarga, kelompok perempuan atau masyarakat, hingga negara (Buvinic, O'Donnel, Knowles, \& Bourgault, 2020). 
Buvinic dkk (Buvinic, O'Donnel, Knowles, \& Bourgault, 2020) menggambarkan bahwa pemberdayaan merupakan sebuah proses panjang yang melibatkan tiga elemen. Elemen pertama adalah sumber daya baik berupa materi, manusia, dan sosial yang mendukung peningkatan kemampuan untuk exercise pilihan termasuk alokasi aktual dan harapan masa depan. Pendidikan, tanah pertanian, dan savings adalah bagian dari sumber daya yang berkontribusi dalam menentukan pilihan dan juga berdampak terhadap elemen pemberdayaan lainnya.

Agensi atau kemampuan untuk melakukan dan memengaruhi perubahan di ruang-ruang penting bagi individu adalah elemen kedua dalam pemberdayaan ekonomi perempuan. Elemen ini dicirikan sebagai elemen subjektif sebab secara konstan berubah dan susah untuk diobservasi ataupun diukur. Agensi dideskripsikan dalam paper (Buvinic, O'Donnel, Knowles, \& Bourgault, 2020) sebagai power within (mis. kepercayaan diri), power to (mis. melamar pekerjaan atau membuka sebuah akun bank), power over (mis. keputusan rumah tangga), dan power with (mis. advokasi bersama serikat buruh untuk perbaikan kondisi pekerjaan). Permisalan dari elemen subjektif ini adalah kepemilikan keahlian dan sumberdaya untuk berkompetisi di pasar, keadilan dan kesetaraan akses institusi ekonomi, serta kekuasaan untuk membuat keputusan dan mengontrol sumber daya dan keuntungan. Elemen terakhir dapat dilihat pada proses pencapaian, yakni hasil akhir dari proses pemberdayaan yang bisa diukur melalui hasil objektif dan subjektif dari pemberdayaan dan kesejahteraan, Pengukuran ini dapat melalui aspek peningkatan pendapatan, kepercayaan diri, dan praktik bisnis.

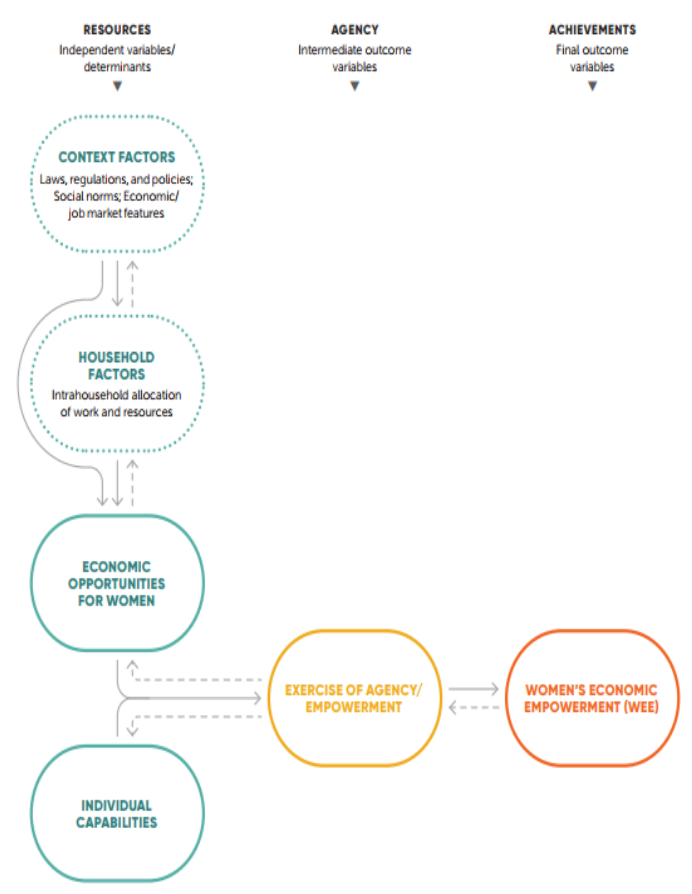

Gambar 2. Kerangka Pemberdayaan Ekonomi Perempuan (Buvinic, O'Donnel, Knowles, \& Bourgault, 2020) 
Meski pemberdayaan perempuan harus dilakukan secara komperehensifdengan maksud tidak hanya berfokus pada satu aspek atau elemen-namun foku korban ops pada pembangunan kapasitas atau capacity building sangat diperlukan dalam konteks permasalahan masyarakat Tegaren. Secara teoretis, pembangunan kapasitas dimaknai sebagai proses pembangunan kemampuan dan keahlian dalam hal mememutuskan dan mengeksekusi kebijakan-kebijakan untuk menuju efisiensi dan efektifitas hasil (Raynor dkk, 2014). Raynor dkk (2014) menerangkan bahwa terdapat tiga kata tanya yang berusaha dijawab oleh pembangunan kapasitas, yakni who (subjek pembangunan kapasitas, seperti individu, organisasi, kelompok organisasi, dan ekosistem), what (objek kegiatan pembangunan kapasitas, seperti pengetahuan atau transfer of knowledge, keahlian, sistem operasional, dan efektifitas), dan how (predikat bentuk) dari pembangunan kapasitas tersebut, yakni pelatihan, bantuan teknis, pengalaman, dan pembelajaran kelompok).

Pembangunan kapasitas dipilih dalam pemberdayaan ekonomi perempuan masyarakat Tegaren karena berfokus pada permasalahanpermasalahan yang dihadapi oleh para perempuan pengrajin besek sebagaima na yang telah dijelaskan pada latar belakang. Tujuan yang ingin dicapai dari pembangunan kapasitas ini adalah agar perubahan dalam aspek atau elemen sumber daya membantu individu atau kolektif memaksimalkan agensi dan capaian milik mereka dalam bidang ekonomi. Hal ini dikarenakan ketiga elemen dalam pemberdayaan saling berhubungan: sumber daya berperan sebagai kondisi di mana pilihan dibentuk, agensi berfungsi sebagai inti dari proses membuat pilihan, dan pencapaian (achievements) adalah hasil dari pilihan yang diambil (Kabeer, McFadden, Arnfred, Dominguez, \& Saadallah, 2001).

\section{METODE PELAKSANAAN}

Pada dimensi konseptual teoretiknya, kegiatan pengabdian masyarakat yang dilakukan di Desa Tegaren menggunakan pendekatan observasi partisipatif. Pendekatan observasi partisipatif menitikberatkan pada posisi peneliti yang terlibat dengan aktivitas partisipan yang diteliti (Cornwall \& Jewkes, 1995). Lebih lanjut, pendekatan partisipatif ini dianggap relevan diterapkan pada 
penelitian yang melibatkan masyarakat lokal untuk secara komprehensif memahami partisipan yang diteliti (Chambers, 1992). Pendekatan observasi partisipatif memungkinkan peneliti atau pelaku kegiatan pengabdian masyarakat untuk menyesuaikan konstruksi metodologi konseptual yang digunakan mengikuti kondisi penelitian/pengabdian masyarakat di lapangan (Rifkin, 1994). Tim pengabdian masyarakat juga menggunakan Participatory Rural Appraisal (PRA). PRA dalam ini digunakan dengan tujuan untuk memelajari kehidupan desa serta kondisi dari, dengan, dan oleh masyarakat desa (Buckley, 2000). Metode ini memungkinkan adanya agenda yang berbeda dari para perencana pembangunan (Buckley, 2000) dan dengan adanya partisipasi serta proses belajar dari masyarakat lokal, pembangunan dan pemberdayaan diharapkan mampu mengatasi persoalan sesuai dengan kebutuhan masyarakat lokal (Siswanto \& Lamsuri, 2008).

Dalam hal pengumpulan data, pendekatan observasi partisipatif dapat dilaksanakan dengan berbagai cara, antara lain: melalui In-Depth Interview dan Focus Group Discussion (FGD). Clark dkk mendeskripsikan wawancara (interview) sebagai sebuah bentuk pengumpulan data kualitatif paling bermanfaat memberi kita wawasan tentang bagaimana individu atau kelompok berpikir tentang dunia mereka (dan) bagaimana mereka membangun 'realitas' dunia (Clark, Riley, Wilkie, \& Wood, 1998). Dengan wawancara pribadi semua pola perilaku yang berhubungan dengan kelompok berusaha dihilangkan sehingga memungkinkan peneliti untuk mendapatkan wawasan yang mendalam dan di atas semua tentang bagaimana subjek bertindak dan bereaksi secara tertentu dalam beberapa situasi (Kaar, 2009). Wawancara, sebagai pendekatan kualitatif, memenuhi kebutuhan untuk mengumpulkan data yang kaya dan menawarkan suara kepada yang diteliti (Tribe, 2010). Terlebih peneliti perlu melihat masalah dari perspektif orang yang diwawancarai, sebelum penjelasan ilmiah (Pereira, Leite, \& Silva, 2013). Hal ini bertujuan untuk menghilangkan pengaruh yang tidak diinginkan penelit $\mathrm{i}$ dari percakapan, dengan triangulasi data dengan sumber lain dan dengan literatur (Tribe, 2010).

Pelaksanaan focus group discussion (FGD) digunakan sebagai metode penggali data bersama observasi. 
FGD adalah jenis wawancara mendalam yang dilakukan dalam kelompok, yang pertemuannya menyajikan karakteristik yang ditentukan sehubungan dengan proposal, ukuran, komposisi, dan prosedur wawancara (Mishra, 2016). FGD melibatkan pengumpulan orangorang dari latar belakang atau pengalaman yang sama guna membahas topik minat tertentu dimana partisipan ditanyai dan menjawab secara bebas perihal kepercayaan, pendapat, atau gagasan. Metode ini dipertimbangkan sebagai sarana untuk menjelajahi wilayah yang tidak diketahui oleh peneliti sebagai alat untuk menjelaskan sikap konsumen, melakukan klarifikasi terhadap temuan, dan memberikan pemahaman yang lebih baik mengenai suatu persoalan.

Untuk mendukung strategistrategi di atas, metode Asset Based Community Development (ABCD) dipakai sebagai pendekatan pemberdayaan ekonomi perempuan partisipatif karena relevan dengan sasaran pemberdayaan pada pengembangan kapasitas dengan menyasar elemen pertama atau resource yang telah dijelaskan pada bagian sebelumnya. Metode, atau bisa juga dirujuk sebagai konsep maupun strategi,
ABCD berorientasi pada bagaimana individu dan seluruh komunitas berkontribusi pada pengembangan mereka sendiri dengan cara: a) mengga li dan memobilisasi kapasitas dan aset desa, b) memodifikasi dan memperbaiki struktur yang ada, dan c) mengartikulasikan serta memvisualisasikan "mimpi" perubahan (Dwiridhotjahjono, Wibowo, \& Nuryananda, 2020). Dalam pendekatan $\mathrm{ABCD}$, local enabler (pemberdaya masyarakat lokal) tidak berfokus pada penggalian potensi, tetapi berfokus pada pengelolaan aset masyarakat yang sudah ada dan menilai serta memperbaiki kekurangan dari asset tersebut (Suksmawati, Alidyan, Febrianita, \& Nuryananda, 2021). Terdapat enam prinsip yang harus diperhatikan oleh local enabler guna menjadi panduanmencapai pemberdayaan yang berkelanjutan dalam $\mathrm{ABCD}$, yakni: a) apresiasi, b) partisipasi, c) psikologi positif, d) deviasi positif, e) pembangunan dari dalam, dan $\mathrm{f}$ ) hipotesis heliotropik (Kretzmann \& McKnight, 1993).

Dalam dimensi praktis, kegiatan pengabdian masyarakat ini akan dilaksanakan dengan empat tahapan, yakni tahap persiapan, tahap 
pelaksanaan program, tahap evaluasi pelaksanaan dan perencanaan improvisasi program, dan tahap pelaksanaan improvisasi program. Persiapan dilakukan untuk mendapatkan kesepakatan antar tim pelaksana, terutama terkait data-data pengembangan desa dan pemberdayaan perempuan lokal kaitannya dengan kerajinan besek bambu. Data terperinci tersebut pada nantinya digunakan untuk membuat pijakan kebijakan teknis yang sesuai dengan kontur dan postur ekonomi-sosial masyarakat Desa Tegaren. Tahap kedua yakni pelaksanaan program. Pada tahap ini, program yang telah direncanakan dan dimatangkan kemudian dieksekusi. Tahap ketiga dari pengabdian masyarakat ini adalah tahap evaluasi pelaksanaan program. Tahapan evaluasi merefleksikan kekurangan dari pelaksanaan program yang terdahulu dan mempersiapkan pengembangan pelaksanaan program sesuai dengan waktu yang tersisa. Sedangkan tahap keempat, yakni tahap improvisasi adalah tahap pelaksanaan program yang sudah dievaluasi sehingga mendapatkan tambahan konsep, metoda, kebijakan, maupun implementasi di lapangan.
Sementara itu, kegiatan pengabdian masyarakat ini dilaksanakan dengan berbagai bentuk kegiatan, yakni 1) penyuluhan sosial (daring), 2) pelatihan decoupage, dan 3) pendampingan (daring). Menurut Peraturan Menteri Sosial Nomor 10 Tahun 2014, penyuluhan sosial merupakan proses pengubahan perilaku yang dilakukan melalui penyebarluasan informasi, komunikasi, motivasi, dan edukasi oleh penyuluh sosial baik secara lisan, tulisan, maupun peragaan kepada kelompok sasaran. Tujuan dari adanya penyuluhan sosial adalah peningkatan pengetahuan dan pemahaman oleh mitra.

Sedangkan pelatihan bisa didefinisikan sebagai proses pendidikan keterampilan jangka pendek dengan metode yang sistematis dan prosedur yang terorganisir sehingga tercapai peningkatan keahlian (Elfrianto, 2016). Decoupage sendiri berasal dari Bahasa Prancis, decouper, yang artinya memotong. Decoupage adalah seni menempelkan potongan-potongan kertas kepada media seni yang akan digunakan. Setelah ditempel, maka potonganpotongan tersebut diberikan warna agar nampak bagus (Ajisuksmo, 2019). Decoupage nampaknya bukan hanya sekedar seni, tapi juga bisa menjadi 
karya seni yang dapat memberdayakan, terumata untuk anak-anak dan perempuan. Seperti yang diulas oleh Sriwartini, yang mana karya seni decoupage telah digunakan untuk memberdayakan anak-anak binaan rumah singgah di daerah Jakarta Selatan (Sriwartini, 2019).

Sementara itu pendampingan (mentoring) adalah metode pemberdayaan atau disebut juga sebagai strategi pemberdayaan masyarakat yang sering digunakan oleh pemerintah maupun organisasi non-pemerintah dalam meningkatkan mutu dan kualitas sumber daya manusia sehingga mampu menyelesaikan masalah secara mandiri. Pendampingan juga merupakan metode atau strategi pemberdayaan yang melibatkan partisipasi masyarakat sasaran. Sehingga, dengan adanya pendampingan, diharapkan pemberdayaan dapat menyelesaikan permasalahan sesuai dengan kebutuhan masyarakat sasaran (Hidayah, 2018).

\section{HASIL DAN PEMBAHASAN}

Melalui pendekatan-pendekatan yang telah disampaikan pada bagian sebelumnya, terdapat dua hasil pengabdian masyarakat yang didapatkan oleh tim pengabdian maupun masyarakat
Tegaren, dalam hal ini khususnya para perempuan pengrajin besek. Hasil pertama adalah peningkatan pengetahuan para perempuan pengrajin besek di Tegaren. Tentu saja peningkatan pengetahuan tersebut memberikan economic leverage bagi ekosistem usaha besek bambu di Tegaren. Hasil kedua adalah munculnya gagasan produk bingkisan pariwisata (oleh-oleh) khas Desa Tegaren, yakni besek hias. Besek yang telah dihias oleh teknik decoupage maupun hiasan pita akan dijadikan bingkisan wisata oleh Kelompok Sadar Wisata Banyu Lumut di Desa Tegaren.

Economic leverage yang dihasilkan dari pengabdian masyarakat ini sebenarnya lebih berupa ke peningkatan kapasitas sumber daya manusia perempuan pengrajin besek dan selisih harga antara besek biasa dengan besek hias, baik yang diolah dengan decoupage maupun besek yang dihias secara manual. Para pengrajin besek bambu di Tegaren sebelumnya pernah mengenal teknik pewarnaan besek. Namun, teknik pewarnaan tersebut lebih kepada pewarnaan manual yang membutuhkan cat minyak dan para pengrajin diharuskan untuk mewarnai keseluruhan besek. Terkadang, hasil 
yang dicapai memang tidak sesuai ekspektasi, mulai dari kelembaban besek yang membuat jamur sampai dengan volume besek yang mengecil walau hanya sangat sedikit. Dengan adanya teknik decoupage dan teknik pita manual, maka kelembaban besek tidak sampai merusak bentuk dan elemen dasar dari besek tersebut. Terlebih jika menggunakan penghiasan manual dengan pita, maka besek yang dihias akan terkesan simple dan elegan. Hal tersebut sangat menarik para wisatawan yang datang ke Tegaren, terutama dari segmentasi kalangan pemuda. Hiasanhiasan tersebut juga menambah harga jual dari besek. Besek yang biasanya dijual Rp. 22.000,- satu kodi, dengan adanya hiasan tersebut sekarang harga besek per kodi naik menjadi Rp. 40.000,- Kenaikan harga tersebut sangat menguntungkan para pengrajin besek karena mereka mendapatkan tambahan keuntungan.

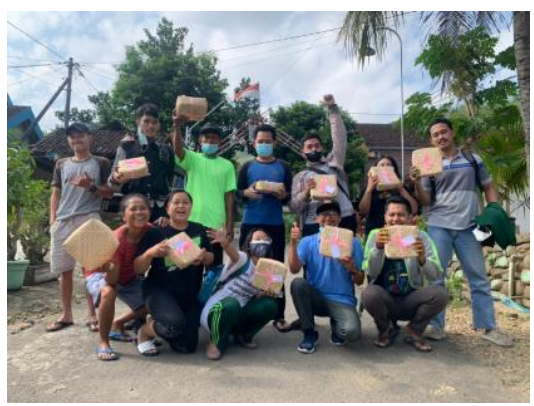

Gambar 3. Salah satu kelompok wisatawan yang berkunjung ke Tegaren dengan bingkisan besek pita (sumber: dokumentasi tim pengabdian masyarakat, 2021)

Dengan menjadikan besek bambu sebagai bingkisan pariwisata, maka permintaan untuk memproduksi ulang besek bambu tidak hanya datang dari pasar-pasar tradisional sebagaimana biasanya, namun juga dari para wisatawan yang akan berkunjung ke Desa Tegaren. Bingkisan ini memiliki nilai yang khas, yakni merupakan produk asli dari Desa Tegaren yang dibuat oleh perempuan-perempuan pengrajin besek di desa tersebut. Oleh karena itu, dalam pengemasan paket pariwisata pun akhirnya Desa Tegaren dapat mengintegrasikan nilai-nilai pemberdayaan perempuan, peningkatan kapasitas sumber daya manusia desa, dan peningkatan kapasitas kepariwisataan desa. Tentu saja hal tersebut dapat memberikan benefit bagi para perempuan pengrajin besek maupun masyarakat desa secara keseluruhan.

\section{KESIMPULAN}

Sehingga bisa disimpulkan bahwa kegiatan pengabdian masyarakat yang dilaksanakan oleh tim abdimas berjalan sesuai dengan tahapan yang direncanakan, meliputi; tahap persiapan, tahap pelaksanaan program, tahap evaluasi pelaksanaan dan perencanaan 
improvisasi program, dan tahap

pelaksanaan improvisasi program.

Sedangkan kegiatannya meliputi; 1) penyuluhan sosial (daring), 2) pelatihan decoupage, dan 3) pendampingan (daring). Sehingga kegiatan pengabdian masyarakat di pengrajin besek Tegaren memiliki dua hasil. Hasil pertama berupa peningkatan pengetahuan para perempuan pengrajin besek yang memberikan economic leverage bagi ekosistem usaha besek bambu di Tegaren. Hasil kedua adalah munculnya gagasan produk bingkisan pariwisata (oleh-oleh) khas Desa Tegaren, yakni besek hias dengan teknik decoupage maupun hiasan pita untuk dijadikan bingkisan wisata oleh Kelompok Sadar Wisata Banyu Lumut di Desa Tegaren.

\section{UCAPAN TERIMAKASIH}

Tim pengabdian menghaturkan terima kasih kepada Pemerintah Desa Tegaren, Kelompok Sadar Wisata Banyu Lumut, dan Badan Usaha Milik Desa Tegaren atas bantuan dan dukungannya.

\section{DAFTAR PUSTAKA}

Ajisuksmo, C. (2019). Pelatihan Kerajinan Decoupage sebagai Cara Untuk Menumbuhkan
Budaya Literasi Kaum

Perempuan. Jurnal Abdimas

Dewantara , 158-170.

Buckley, M. E. (2000). Beyond the rhetoric of empowerment: $A$ critical analysis on gender, participation, and empowerment. Dalhousie University.

Buvinic, M., O'Donnel, M., Knowles, J.

C., \& Bourgault, S. (2020).

Measuring women's economic empowerment. Center for Global Development.

Chambers, R. (1992). Rural Appraisal:

Rapid, Relaxed, and Participatory. Institute for Development Studies Papers .

Clark, M. A., Riley, M. J., Wilkie, E., \& Wood, R. C. (1998).

Researching and writing dissertations in hospitality and tourism. International Thomson Business Press.

Cornwall, A., \& Jewkes, R. (1995). What is Participatory Research? Soc.Sci.Med. , 1667-1676.

Dwiridhotjahjono, J., Wibowo, P., \& Nuryananda, P. F. (2020). Bamboonomic: Ekonomi Bambu Pendukung Desa Wisata 
Tegaren. Jurnal Master

Pariwisata (JUMPA), 117-124.

Elfrianto. (2016). Manajemen Pelatihan

Sumber Daya Manusia dalam

Meningkatkan Mutu Lulusan.

Jurnal Edu Tech .

Hidayah, N. (2018, August 20). Kajian

Teori Pendampingan. Surabaya,

East Java, Indonesia.

Kaar, M. (2009). A ciritical

investigation of the merits and

drawbacks of in-depth

interviews. GRIN Verlag.

Kabeer, N., McFadden, P., Arnfred, S.,

Dominguez, E., \& Saadallah, S. (2001). Discussing Women's

Empowerment-Theory and

Practice. Stockholm: Sida.

Kretzmann, J. P., \& McKnight, J. (1993). Building communities

from the inside out. Illino is:

Center for Urban Affairs and

Policy Research.

Mishra, L. (2016). Focus group

discussion in qualitative

research. Techno Learn .

Pereira, R. N., Leite, D. C., \& Silva, J.

A. (2013). The interview:

methodological framework in

the study of tourism and

economis the Faro airport (1946-
1973). Spatial and

Organizational Dynamics

Discussion Papers , 88-107.

Rifkin, S. (1994). Participatory

Research and Health. The

International Symposium on

Participatory Research on

Health Promotion. Liverpool:

Liverpool School of Hygiene

and Tropical Medicine.

Siswanto, B., \& Lamsuri, M. (2008).

Kemiskinan dan Perlawanan

Kaum Nelayan. Laksbang

Mediatama.

Sriwartini, Y. (2019). Pendampingan

Membuat Decoupage dan

Pemasarannya Melalui Media

Online. Jurnal Pengabdian

Nusantara , 181-190.

Suksmawati, H., Alidyan, M.,

Febrianita, R., \& Nuryananda, P.

F. (2021). Besek Tegaren:

$\mathrm{ABCD}, \mathrm{CBT}$, dan Glokalisasi

dalam Satu Kemasan. Sawala:

Jurnal Pengabdian Masyarakat,

Pembangunan Sosial, Desa dan

Masyarakat, 9-18.

Tribe, J. (2010). Tribes, territories, and networks in the tourism academy. Annals of Tourism Research , 7-33. 